\title{
Correction to: Propofol but not dexmedetomidine produce locomotor sensitization via nitric oxide in rats
}

\author{
Tuğçe Uskur $^{1}$ • Ayşe Özçetin Şenöz ${ }^{2}$ • Burcu Çevreli ${ }^{2}$ - Aydın Barlas ${ }^{3}$ • Tayfun Uzbay ${ }^{2,4}$ \\ Published online: 20 November 2020 \\ (C) Springer-Verlag GmbH Germany, part of Springer Nature 2020
}

\section{Correction to: Psychopharmacology}

https://doi.org/10.1007/s00213-020-05707-5

Page 3, Table 1, second line of table: The control group was injected with saline plus saline, not saline plus propofol. Thus injections in the second line of Table 1 should be corrected as saline saline.

The original article has been corrected.

Publisher's note Springer Nature remains neutral with regard to jurisdictional claims in published maps and institutional affiliations.

The online version of the original article can be found at https://doi.org/ $10.1007 / \mathrm{s} 00213-020-05707-5$

Tayfun Uzbay

tuzbay@uskudar.edu.tr; uzbayt@yahoo.com

1 Faculty of Medicine, Department of Medical Pharmacology, Beykent University, Istanbul, Turkey

2 Neuropsychopharmacology Application and Research Center (NPFUAM), Üsküdar University, Istanbul, Turkey

3 School of Medicine, Department of Pharmacology, Altınbaș University, İstanbul, Turkey

4 Faculty of Medicine, Department of Medical Pharmacology, Üsküdar University, İstanbul, Turkey 